\title{
ЮВІЛЕЙ ВЕРГУНОВА ВІКТОРА АНАТОЛІЙОВИЧА!
}

\author{
B. A. Хаджиматов, кандидат сільськогосподарських наук \\ Державна служба з охорони прав на сорти рослин, \\ С. В. Гаценко, кандидат економічних наук \\ Український інститут експертизи сортів рослин, \\ В. В. Шелепов, доктор сільськогосподарських наук \\ Державна наукова сільськогосподарська бібліотека НААН України
}

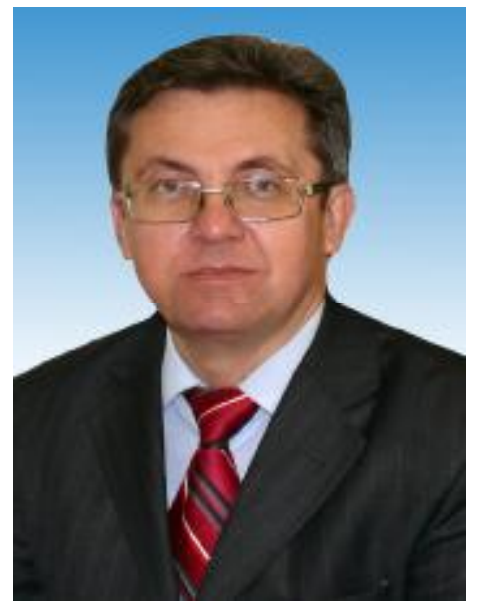

Третього червня 2010 р. виповнилось 50 років від дня народження Віктора Анатолійовича Вергунова, доктора габілітації сільськогосподарських наук, професора, директора Державної наукової сільськогосподарської бібліотеки НААНУ, члена Національної спілки журналістів України, першого головного редактора науково-практичного журналу «Сортовивчення та охорона прав на сорти рослин».

Віктор Анатолійович Вергунов народився в с. Дернівка Баришівського району Київської області. Закінчив агрономічний фракультет Ворошиловградського сільськогосподарського інституту (1982 р) та історичний фракультет ДВНЗ Переяслав-Хмельницького державного педагогічного університету імені Григорія Сковороди (2008р.). Трудову діяльність розпочав у 1982 р. агрохіміком Панфильської дослідної станції з освоєння боліт Українського НДІ землеробства (Яготинський район, Київська область). Після закінчення у 1988 р. аспірантури ННЦ «Інститут землеробства НАAНУ» працював у ньому спочатку молодшим науковим співробітником, згодом науковим співробітником лабораторії захисту ґрунтів від ерозії, потім (1993 р.) - завідувачем сектору відділу науки, а з 1998 р. - завідувачем відділу інформаційного та консультаційного забезпечення АПВ Київської області. У 2000 р. призначений директором ДНСГБ HAAHY.

Упродовж 1982-2003 рр. виробнича, наукова та освітня діяльність Вергунова В. А. спрямовувалась на вдосконалення технологічних підходів до екологічно збалансованого ведення сільського господарства на меліорованих ґрунтах Лісостепу України, результатом якої стали захист кандидатської дисертації на тему «Продуктивність бобово-злакових травосумішок залежно від зрошення та мінерального живлення при структурній меліорації мілкоторфовищ Лісостепу України» в Українській сільськогосподарській академії (1992), та докторської дисертації «Природоохоронне адаптивно-ландшафтне землеробство в басейнах малих річок Лісостепу України» в Дебреценському університеті (Угорська республіка) (2003).

Працюючи директором ДНСГБ НААНУ В. А. Вергунов якісно змінив пріоритети діяльності й організаційну структуру бібліотеки, переорієнтувавши її в наукову установу I категорії по своїй сутті. Ним у 2001 р. створюється єдиний у країні Центр історії аграрної науки. При Центрі відкрито аспірантуру, докторантуру та спецраду із захисту дисертацій. За час існування центру захищено 50 докторських і кандидатських дисертацій.

Науково-організаційна та методи- 
чна діяльність профресора В. А. Вергунова як директора головної книгозбірні аграрної галузі та віце-президента Асоціації бібліотек України, що за своїм фондом $є$ третьою галузевою бібліотекою світу, визнана на державному рівні, а також за кордоHOM.

Широко відома журналістська та публіцистична діяльність В. А. Вергунова на сторінках провідних періодичних видань з різних проблем організації бібліотечної справи, а також маловідомих сторінок історії. Незалежній Україні вперше повернуто не один десяток славетних імен українців.

За багаторічну сумлінну працю В. А. Вергунов нагороджений Почесною грамотою Кабінету Міністрів України (2002), Грамотою (2002) та Почесною грамотою Верховної Ради України (2005), медаллю Верховної Ради України «Десять років незалежності» (2003), Почесною відзнакою НААНУ (2007), орденами «За заслуги III ступеня» (2009) та «За заслуги в сільському господарстві» (Республіка Франція, 2010), також йому присвоєно почесні звання: «Заслужений працівник сільського господарства України» (2003) та «Заслужений діяч науки і техніки Автономної Республіки Крим» (2010). Його роботи високо оцінені - отримали премії в галузі науки і техніки: ім. О. Бойченка (1990), ім. Островського (1991), НАН України для молодих вчених (1995), НААНУ - «За видатні досягнення в аграрній науці» (2001), АР Крим (2006), імені М. С. Грушевського НАН України, а також срібну медаль ВДНГ УРСР (1990). В. А. Вергунова обрано почесним профресором Сарвашського інституту водного господарства та охорони навколишнього середовища (2003, Угорщина), Луганського НАУ (2001); він отримав відомчі нагороди Мінагрополітики України, Міносвіти України, МНС України, Держводгоспу України. Результатом даного періоду роботи стали публікації понад 220 наукових і науково-методичних праць, з яких 10 монографрій, 10 підручників (у співавторстві) та наукове керівництво В. А. Вергунова у підготовленні до .захисту 9 кандидатських дисертацій.

В. А. Вергунов не втрачає творчої наснаги, веде велику наукову, консультативну і педагогічну роботу. Бажаємо Вік- тору Анатолійовичу міцного здоров'я, творчого довголіття та успіхів у справі його життя. 